\title{
Simmering in the Soviet pot: language heterogeneity in early Soviet socio-linguistics
}

\author{
Mladen Uhlik
}

Published online: 16 September 2008

(C) Springer Science+Business Media B.V. 2008

\begin{abstract}
At the beginning of the '30s - the period of lively debates on the relation between language and society - one of the main issues in linguistics was language heterogeneity. On the example of the texts by Boris Larin, Georgij Danilov and Lev Jakubinskij we shall compare two attitudes about unity and division of a language. If the studies by Larin and Danilov in various ways establish divisions in society and language at the end of the '20s, in the ' 30 s there is a marked tendency to recognize language unity and the cohesiveness of the proletarian society, as seen in sociolinguistic analyses by Jakubinskij. The conclusion, suggested at the end of this exposition, claims that the idea of one national language grows in importance in the discourse of the Soviet linguistics at the beginning of 1930s. Disappearance of the contemporary language heterogeneity in the discourse of Soviet linguists of the period corroborates how linguistics adapts to the political conceptions of society.
\end{abstract}

Key words Language heterogeneity · Language conflicts ·

Delimitation among languages - Division of language(s) - Proletarian language ·

Cohesiveness of the proletarian society $\cdot$ National language

During the period of lively debates in the Soviet Union on the relationship between language and society from the 1920s until the beginning of the 1930s, one of the main issues in linguistics was language heterogeneity. As the period after the Revolution was characterized by attempts to insert approaches from social science into linguistics, the question of language unity became related to the question of

M. Uhlik $(\bowtie)$

Section des Langues slaves, University of Lausanne, 1015 Lausanne, Dorigny, Switzerland

e-mail: mladen.uhlik@gmail.com

M. Uhlik

Institutum Studiorum Humanitatis, Ljubljana, Slovenia 
social division and unity. In the following short article I shall try to highlight two different approaches to the question of unity and division in language developed in the works of Boris Larin and Georgij Danilov, both of whom emphasized, in different ways, the divisions in language and society at the end of the 1920s. This particular issue gained particular importance in Soviet linguistics following Stalin's announcement of the Great Turning Point in 1928. At this time there was a shift from emphasizing language division to asserting its unity, which I will discuss with reference to the socio-linguistic analyses of Lev Jakubinskij. In his view, the dominant tendency of that time was to recognize language unity, while confirming the cohesiveness of proletarian society. I would like to emphasize that Larin, Danilov and Jakubinskij have been selected precisely because their respective works embody the various views on linguistics, its methods and its object.

1.

Firstly we will turn to Boris Larin's research on urban speech, which was developed in his writings On the Linguistic Study of the City (O lingvističskom izučenii goroda 1928) and The Linguistic Characteristics of the City (K lingvisticeskoj kharakteristike goroda 1928). In these texts, Larin noted that the methods and object of Russian linguistics before the Revolution, which were based on the study of the literary language and rural dialects, were hardly sufficient to describe the contemporary linguistic situation. In a time of rapid industrialization, with massive migration to urban areas, Larin argued that the object of linguistic exploration should shift to urban colloquial speech.

Unlike literary language and rural dialects, urban speech is a hybrid phenomenon: at a time when cities are growing, the whole of the urban population is bilingual. By this Larin meant that it uses several systems of speech (rečevye sistemy). In the spirit of the Soviet linguistics of the 1920s, the characteristic feature of these systems is social rather than individual. However, the keyword of two Larin's texts on urban speech from the end of the 1920s is 'argot.' In his earliest writings on the subject, argot represents the first and principal speech system of every social group. Contrary to literary language or an urban dialect, argot is always accompanied by a parallel system - by some other language-with which it is linked. The main feature of this concept of urban bilingualism is the absence of a precise delimitation between argot and the other system. This other system is not defined but, Larin argued, it could be defined if we had sufficient data. What is particular to Larin, writing in 1928 , is that the second system was never the literary language.

Although these definitions of argot, proposed in On the Linguistic Study of a City are not precise, it is important to emphasise the following points: Firstly, Larin's texts belong to the popular linguistic discourse in the '20s which supposed the existence of a diversity of languages and subsystems within the national language. Thus, in the mid-1920s research on social dialects briefly flourished in the Soviet Union and there were also numerous attempts at standardisation of the languages 
that in the imperial age had been marginalised and socially dysfunctional (e.g. Belorussian, Ukrainian, and many Caucasian languages).

Secondly, in this text Larin mentions the possibility of influence from the bottom up (i.e. from the underprivileged social groups upon the elite). For instance, according to Larin, the language of peddlers, argot and colloquial language can influence the formation of the normative language. Larin completely changed his views in 1931 when he established that literary language played a major role in the creation of all linguistic varieties, among them argot.

Thirdly, Larin's discourse in the 1920s is distinguished by its comparative character. Thus, unlike Danilov or Jakubinskij, he identified the same phenomena such as the popularity of the language of peddlers in large cities, or its influence on literary language in the Soviet Union, as well as in the western world. The comparison of the Russian language situation with that of the West is very rare in Soviet linguistics after 1930.

In his subsequent study The Linguistic Characteristics of the City (1928) Larin managed to widen the debate. Here language is considered as a factor in social integration. It unites the members of a language community but, at the same time, it exerts a role in social differentiation, which is an important element in the linguistic discourse of the 1920s. Thus, cities-conglomerates of different social groups having different needs and interests-are centres of language conflicts. Urban language heterogeneity is defined from two perspectives. Firstly, every city is a meeting point of groups, each one possessing its own language/dialect (raznojazycie goroda). Secondly, the members of every group use several languages/dialects (poliglotizm grazdan). The drawback of this text, which indicates the limits of Larin's methods, is the lack of distinction between the notions of language, dialects and speech.

In spite of its unstable terminology (terms such as language, speech and dialect are not clealry delineated), however, the rejection of 'linguistic monism' remains constant in these texts. Larin rejected the hypothesis of the existence of a parent language as well as the dogma of national monolingualism. But Larin also rejects the very popular ideas of his time: the monolingualism of social groups (which is found in Danilov) and the vision of one universal language in the future, which was advocated by Nikolaj Marr. The consequence of this rejection involved, once again, the emphasizing of the diversity of language.

According to Larin, every effort of a linguistic or political theory to associate a dialect with some social collective is futile because inside every community, and among communities, 'language conflicts and the hatred caused by languages will exist forever.' (Larin 1977). In spite of relating the conflicts to polyglossia, the later is not evaluated negatively by Larin. Moreover, he considers it necessary for political authorities to take full account of the phenomenon, (e.g. by stimulating polyglossia and poly-dialectalism in the educational system).

Another consequence of the acceptance of polyglossia is a change of perception of the normative language which is, in Larin's opinion, always in contact with other dialects and languages. In spite of his unstable terminology and some contradictions, Larin's texts are quite representative of the discourse on language in the 1920s when language diversity was emphasized. 


\section{2.}

If Larin accepted the idea of language as a factor of social differentiation, the members of the Jazykfront group, who declared themselves Marxist linguists, went further in the sociological interpretation of language. At the end of the 1920s they conducted research into the recent developments of the language of the period. Accordingly, they chose proletarian language, which, in their view, represented the most important developmental force in the language of that period. ${ }^{1}$

As an example of the positions of the Jazykfront I will consider the writings of Georgij Konstantinovič Danilov, the first Soviet Africanist: The Language of a Social Class (Язык общественного класса (по даннылм говора мест. Белик Полтавского округа 1929; based on data on the Belik commune-Poltava Region) and Features of Workers' Speech Styles (Черты речевого стиля рабочего 1931).

Danilov conducted his research in the second half of the 1920s in the Ukrainian commune of Belik. The study consisted of identifying types of every class of citizens and of demonstrating how the particular speech of each of these classes contributes to the class struggle. Danilov shares a view popular among Soviet linguistics of the time: language diversity is a result of the various types of different class psychologies, and which reflect socio-economic conditions.

Danilov's method in these texts allows us to see how his assumptions about class psychology are compatible with the language usage of these classes. According to the prevailing atmosphere of the time, the perception of psychology is constrained to the psychology of social groups, that is to say-to the psychology of classes.

While the ethnic population in Belik was homogeneous, this was not the case with language distribution. Part of its population spoke Ukrainian, another part mixed it with Russian, and a tiny minority was bilingual. Danilov interpreted this heterogeneity in terms of social class structure by comparing the differences between the wealth of vocabulary, morphological, phonetic and syntactic structures, but also the emotive character in language usage and in the manner of speaking (tonus recii). Danilov presented the social stratification of the commune as including the following classes: the peasants (divided into the poor-bednjaki, the average, and the rich kulaki exploiting the former), the workers, the merchant bourgeoisie and the local executive (including members of Party cells, teachers, intelligentsia, etc.). The aim of this research was to carry out an analysis of the numerous Ukrainian parlances in which any language usage will be a result of a conscious relationship (soznatel'noe otnošenie). According to Danilov, certain classes do not develop a complex mental structure, which is reflected in their use of less developed linguistic means. On the other hand, some classes (such as the rich peasants and the

\footnotetext{
1 See Bazylev and Neroznak (2001, pp. 90-120). The group was active from 1930 to 1932 and fought the doctrine of Nikolaj Marr and his adepts. Among the prominent figures of Jazykfront were T. P. Lomtev, G. K. Danilov, Ja. V. Loja. P. S. Kuznecov. Due to the pressures of the Marrists, the group fell apart in 1933 (Alpatov 2003).
} 
Party executive) are superior in psychology and in language usage. This superiority is related to the complexity of their everyday activities. ${ }^{2}$

Danilov argued that one of the consequences of this hierarchy is that the linguistic consciousness of the rich peasants is more developed than that of the poor peasants. So, for political reasons, the kulaks avoided using the Russian word 'krasnyj' preferring the Ukrainian word 'červonyj;' while the poor peasants did not use any term other than the Ukrainian one. Skilled workers and local executives are the highest rank in this hierarchy of classes as they are bilingual. They use Russian, the language of the October Revolution, but they also speak Ukrainian in order to stay close to the masses. In Ukrainian, according to Danilov, they have recourse to Sovietisms that, contrary to the archaisms used by the peasants, refer to the new reality. The peasants' language is seen as inferior because it is archaic and reduced exclusively to the terminology of agriculture. The adversary of proletarian language is bourgeois language which means the usage of literary language and loan words in order to differentiate it from the masses (Danilov 1929). Although bilingualism in this situation is evaluated positively, the ideal would be to find a language which could unify the workers and masses. In Danilov's opinion, the proletarian language should be the element of cohesion in society, divided because of class consciousness. According to the same author, this language should be Russian as it is related to the Revolution (Danilov 1929). Here we need to keep in mind that this is a proposal and not a prescription.

After his retraction in 1931, Danilov published the study, Features of Workers' Speech Styles (Danilov 1931b). In this work he applies his former method to workers' language. His starting point in language description is the workers' psychological characteristics. This deductive method belongs to the psychology of types. Simplicity, spontaneity, and harshness are the most widespread features, in Danilov's opinion, and language ensures the confirmation of this psychological portrayal. In this demonstration, he employs linguistic terms such as neologism, archaism, inversion, and the parodic use of some styles (sniženie stilja).

The novelty of his text is expounded in the first lines. The class structure of language, particularly that of the workers, reveals itself most evidently in its style (in the fields of lexicology, syntax, morphology and phonetics). The introduction of 'style' as a term allows Danilov to distinguish two linguistic functions. Firstly, he interpreted language as a means of communication and, secondly, language as a means of expression. Lev Jakubinskij, our next hero, in his article 'Protiv Danilovščini' (1932), criticized Danilov for relying on the opposition introduced by a 'bourgeois' Swiss linguist Charles Bally: the opposition between the intellectual function and the expressive function of language. In this context, Jakubinskij, as we shall see, distinguished two functions: language as a means of communication and language as ideology. Before passing to Jakubinskij, we should mention that Danilov's concept of style is quite similar to his idea of language consciousness: a linguistic fact obtains its stylistic value when it is perceived as such.

\footnotetext{
${ }^{2}$ It is worth noting that as a result of this mechanistic notion and fierce criticism from other linguists, Danilov had to publicly renounce his views and published an article 'My mistakes' in 1931 (Danilov 1931a). Such public recantations and renouncements were a part of Soviet everyday in the late ' 30 s.
} 
3.

Among the mentioned linguists Lev Jakubinskij achieved the highest recognition. A former Petersburg student of Baudouin de Courtenay, initially a Formalist and one of the founders of the OPOJaZ, moved away from the ideas of Formalists after the Revolution. Already from 1923 he moved closer to Marr, from whom he gradually became estranged in the 1930s. Jakubinskij was a prominent researcher at ILJAZV (Institut sravnitel'nogo izučenija literatur i jazykov Zapada i Vostoka-Institut for the Comparative History of the Literatures and Languages of the West and East, later GIRK, Gosudarstvennyj institut rečevoj kul'tury-State Institute for Discursive Culture).

Given the complexity of Jakubinskij's scholarly work, we will focus only on the issues concerning the relationship between language and society at the beginning of the 1930s and its connection with the class struggle.

Lev Jakubinskij, then head of linguistic research at GIRK, criticized Danilov's studies for the naivete of their descriptivism and for his attempt to link linguistic categories to the psychological features typical of different classes.

Unlike Danilov, the ex-Formalist thought that empirical and synchronic description is not enough to highlight the style of proletarian language. Any 'Marxist' linguistic analysis, in Jakubinskij's view, demands a historical approach that will reveal the regularities of development in the object studied. Using this historical approach he explored the issue of proletarian style in a series of articles published at the beginning of the 1930s in Literaturnaja učeba, a review edited by Maxim Gorky (Ivanov and Jakubinskij 1930; Ivanov and Jakubinskij 1932; Jakubinskij 1930a, b).

If Larin and Danilov's writings are descriptive (aiming to describe urban language or the language of different classes), those by Jakubinskij are rather prescriptive. His purpose is to educate young writers who, coming from the workers' or peasants' classes, would be the ideal representatives of the proletarian class. According to Jakubinskij, the main feature of the Russian proletariat is that it has been recruited mostly from the peasantry. There are none of the comparative and universalistic attitudes that can be found in Larin's writings in Jakubinskij's text. Thus, the proletarian and his language are particular and related to Russian history: "In this lecture we are going to tackle the Russian proletariat, whose conditions of formation and development are to a certain extent peculiar in comparison to the conditions in the other countries." (Ivanov and Jakubinskij 1932). Thus, Jakubinskij's 1930 study was entitled 'The Class Structure of Modern Russian Language: Language of the Peasantry' (Jakubinskij 1930a).

The history of the language of the peasantry, which is connected with the emergence of proletariat, passes through three periods (Jakubinskij 1930a):

a. Feudalism, the time of society divided into many hermetic enclaves where different dialects were spoken-the time of diversity;

b. Capitalism - the time when the bourgeoisie, owing its origin to the emergence of cities, strove to impose-in view of its own interests-one common national 
language; This is the time of strong oppositions: The tendency towards the language unity (the bourgeoisie tries to generalize its language) is opposed to the unequal nature of capitalism and to the class struggle. Every class attempts to affirm its language. Jakubinskij believed that it was the time of the emergence of the proletariat and of the conscious relationship (soznatel'noe otnořnie) of every class toward its own language. The term 'conscious relationship' is a commonplace formulation that can be found in Danilov.

c. The time of the dictatorship of the proletariat when, with the disappearance of classes, all language heterogeneity will be extinguished (Ivanov and Jakubinskij 1930).

Jakubinskij emphasized that language is one of the principle factors of the division and cohesion of groups (an idea that was also shared by Larin), and therefore can be used as a weapon in a class struggle (Ivanov and Jakubinskij 1932). As we have already seen, the Russian working class was recruited from the peasants who spoke different regional dialects. To reach class unity, the proletariat has to 'liquidate the linguistic hereogeneity' (raznojazyčie) (Ivanov and Jakubinskij 1932). The latter issues from the survival of different rural languages, that is, differences that threaten the formation of one autonomous proletarian language and consequently its unity. By developing its own language, the proletariat would be able to pass from 'a class in itself' to 'a class for itself'- the conscious class, well organized and aware of its' own interests. Thus the proletariat would be able stand against the bourgeoisie (Jakubinskij 1930a; Ivanov and Jakubinskij 1932). If most of the linguists of the period who incorporated Marxism into their theory agreed that language should be a 'weapon in class struggle,' they were divided on the issue of what would be the language usage that is proper to the proletariat, to would allow it to withstand its class enemy - the bourgeoisie.

Danilov considered that the proletariat should develop its own language, distinct to the speech of other classes due to its pronunciation, grammar and special vocabulary. By contrast, Jakubinskij in his 1932 text written with Ivanov, asserted that the working class should adopt the national language, as other acquisitions of bourgeoisie culture (Ivanov and Jakubinskij 1932). Thus, in this text from 1930s two authors refer to Lenin in order to reject the idea that the proletariat should completely break with culture and tradition by forming its own substitute. The claim that 'the objective interests of working class force it to assimilate the various achievements of bourgeoise culture for its own needs' (Ivanov and Jakubinskij 1932), represented a radical refusal of an idea, particularly supported by the Proletkul't movement, that the working class should create its own culture, completely devoid of bourgeois influence.

Within a national culture or language, in this author's view, the proletariat has to develop its own language style that will not be different from literary language in its linguistic features. The proletariat's opposition to the bourgeoisie, its class enemy, does not concern pronunciation, grammar or vocabulary and these features where language operates as a means of communication. This assertion was founded on a distinction between the two language aspects. Thus, Jakubinskij distinguished the function of a language as a means of communication (language form) from the 
function of a language as ideology (language content). ${ }^{3}$ Both of these functions coexist in language, but come into contradiction with each other in the course of their evolution which is, in its turn, conditioned by socio-economical factors.

According to Jakubinskij, the proletariat should adopt the linguistic norms of the national language as a means of communication that "the bourgeoisie created for its interests." But proletarian speech style, according to Jakubinskij, should have its proper ideological aspect (Ivanov and Jakubinskij 1932). In Jakubinskij's view, the latter concerns the specific usage of national linguistic material: the selection of these linguistic elements that would be proper to attain certain objectives and a particular attitude toward a language material by subjecting it to particular ideological evaluations (ocenki). This linguistic usage would form the so-called 'proletarian speech style' that would reflect the working class psychology and ideology (Ivanov and Jakubinskij 1930). As we can see, despite his criticisms, Jakubinskij shared with Danilov the idea that the language usage reflects class psychology.

Its particularity will be evident at the ideological level. According to Jakubinskij, the proletariat forms its speech style in such a way that it reflects the proletarian psychology and ideology (Ivanov and Jakubinskij 1930). As we can see, despite his criticisms, Jakubinskij shared this logic with Danilov. But there is something else concerning the proletarian speech style that is important for Jakubinskij. Although this style emerges spontaneously, in the communication of the working class and in its struggle, it is above all created by the writers and ideologists of the proletariat. So, in comparison to Larin, there is less influence from the bottom up in the emergence of language (the object of study).

At this point, I would like to highlight a certain epistemological shift, in which Jakubinskij differs from both Larin and Danilov. The work of Jakubinskij from the early 1930s aims not only to surpass the mere attempts at describing the linguistic situation but also to direct language usage - the way in which writers should make use of language. While this is a clear attempt at directing the use of language, Jakubinskij's idea of language planning is extended to this science in its entirety. Linguistics should be created to serve a certain purpose, just like all other sciences. Thus, his linguistics becomes a modern science, which not only describes, but also produces its own object. Following the spirit of the time, language-as a product of linguistics-becomes a means by which the social classes, i.e. speech collectives, develop consciousness of their needs. Contrary to both of the above-mentioned authors, Jakubinskij's interpretation of society during the era of the dictatorship of the proletariat, rests on a discourse, which excludes 'language war' (as opposed to

\footnotetext{
3 The opposition is comparable to that of Vasilij I. Abaev who in his studies (Abaev 1934, 1936) distinguished two language functions: as a technique and as an ideology. Yet in Abaev's case, this differentiation is more elaborated and specified: the language form is always a technique, but the opposition concerns two aspects of semantics: in Abaev's view, the technical semantics indicates what is expressed by a lexical unit (or, in modern parlance, its contemporary denotative meaning), while the ideological semantics manifests how it is expressed-that means : what was the first meaning that would, according to Abaev, reflect the world view and representation of the social and historical milieu where the lexical unit appeared (Abaev 2006).
} 
Larin's view), as well as the class struggle (in opposition to Danilov). The evolution of each of the classes is determined by the history of its national language.

To conclude, it is clear that the idea of a single national language grows in importance in the discourse of Soviet linguistics at the beginning of the 1930s. The disappearance of contemporary language heterogeneity (raznojazycie) and its relegation to the capitalist past (where it had a function in the emergence of the conscious relationship of every class toward its own language) in the discourse of Soviet linguists of the period is symptomatic of the way linguistics adapted to the social and political ideas of the day, or more precisely- to the Soviet reality of the 1930s. Such a non-conflictual and harmonious vision of society, excluding contemporary language heterogeneity, complies with the spirit of Stalinist period which at the beginning of 1930s announced the end of the Revolution.

\section{References}

Abaev, V. (1934). Jazyk kak ideologija i jazyk kak texnika. Jazyk i myslenie, 2, 33-54.

Abaev, V. (1936). Ešče o jazyke kak ideologija i kak texnika. Jazyk i myslenie, 6-7, 5-18.

Abaev, V. I. (2006). Stat'I po teorii i istorii jazykoznanija. Moskva: Nauka.

Alpatov, V. M. (2003). La linguistique marxiste en URSS dans les années 1920-1930. Cahiers de l'ISLS 14 (Le discours sur la langue en URSS à l'époque stalinienne). pp. 5-22.

Danilov, G. (1929). Jazyk ob̌̌čstvennogo klassa (po dannym govora mestecka Belik Poltavskogo okruga). http://www2.unil.ch/slav/ling/textes/ DANILOV29/txt.html

Danilov, G. (1931a). Moi ošibki. http://www2.unil.ch/slav/ling/textes/Danilov31.html

Danilov, G. (1931b). Čerty rečevogo stilja rabočego. http://www2.unil.ch/slav/ling/textes/ DANILOV31c/txt.html

Ivanov A. M., Jakubinskij, L. (1930). Klassovyj sostav sovremennogo russkogo jazyka: jazyk krest'janstva. Literaturnaja učeba, 6, 51-66.

Ivanov A. M., \& Jakubinskij, L. (1932). Jazyk proletarjata. Očerki po jazyku dlja rabotnikov literatury $i$ dlja samoobrazovanija (pp.107-123). Leningrad/Moskva.

Jakubinskij, L. (1930a). Klassovyj sostav sovremennogo russkogo jazyka: jazyk krest'janstva. Literaturnaja učeba, 4, 80-92.

Jakubinskij, L. (1930b). Klassovyj sostav sovremennogo russkogo jazyka: jazyk proletarjata. Literaturnaja učeba, 7, 22-23.

Larin, B. (1977). Istorija russkogo jazyka i ob̌̌če jazykoznanie (izbrannye raboty). Moskva: Prosveščenie.

\section{Reference and Sources}

Bazylev, V. N., \& Neroznak, V. P. (2001). Sumerki lingvistiki: iz istorii otečestvennogo jazykoznanija. Moskva: Academia.

Brandist, C. (2003). Bakhtine, la sociologie du langage et le roman. Cahiers de l'ISLS 14 (Le discours sur la langue en URSS à l'époque stalinienne) (pp. 59-85).

Brandist, C. (2006). The Rise of Soviet Sociolinguistics from the Ashes of Völkerpsychologie. Journal of the History of the Behavioral Sciences, 42(3), 261-277.

Brandist, C., Shepherd, D., \& Tihonov, G. (2004). The Bakhtin circle: In the master's absence. Manchester, New York: Manchester University Press.

Sériot, P. (1995). Changements de paradigmes dans la linguistique soviétique des années 1920-1930. Histoire Epistemologie Langage (Une familière étrangeté: la linguistique russe et soviétique) KHVII/2 (pp. 235-251).

Von Timroth, W. (1986). Russian and Soviet sociolinguistics and taboo varieties of the Russian language. München: Verlag O. Sagner. 